\title{
PERANAN NEGARA DAN HUKUM DALAM MEMBERANTAS KEMISKINAN DENGAN MEWUJUDKAN KESEJAHTERAAN UMUM
}

\author{
Yohanes Suhardin ${ }^{1}$
}

\begin{abstract}
The state has a strategic role to stop poverty. Such attempts means a liberation for the poor and in accordance with the national ideals (read: the nation) it is to promote public welfare. Thus, the nation, in this case the governments as the ruler of the state, should firmly hold on the national ideals through legal products that essentially accommodate the values of social justice to realize the prosperity. The basic reason is that nature of the law is justice, thus in the context of the public rule, the law is to create a social justice. In this case, the law which bases on social justice is the way to the common prosperity that Indonesia could free from poverty in a relatively short time.
\end{abstract}

Keywords: state, government, law, poverty, social justice, public welfare

\begin{abstract}
Abstrak
Peranan negara dalam memberantas kemiskinan sangat strategis. Memberantas kemiskinan berarti membebaskan warga negara yang tergolong miskin. Peranan yang strategis tersebut mengingat cita-cita nasional (baca: negara) adalah terciptanya kesejahteraan umum. Oleh karena itu, negara yang dalam hal ini pemerintah sebagai penyelenggara negara harus berpegang teguh pada cita-cita nasional tersebut melalui produk hukum yang sarat dengan nilai keadilan sosial demi terwujudnya kesejahteraan umum. Sebab, hakikat dari hukum itu adalah keadilan, maka dalam konteks bernegara, hukum dibentuk untuk terciptanya keadilan sosial. Hukum yang berkeadilan sosial diyakini sebagai jalan menuju kesejahteraan umum sehingga bangsa Indonesia dalam waktu relatif singkat dapat memberantas kemiskinan.
\end{abstract}

Kata kunci: negara, pemerintah, hukum, kemiskinan, keadilan sosial, kesejahteraan umum

\section{Pendahuluan}

Tujuan didirikannya negara Republik Indonesia adalah untuk mewujudkan kesejahteraan umum dan keadilan sosial bagi seluruh rakyat Indonesia. Hal tersebut tertera dalam alinea keempat Pembukaan UndangUndang Dasar Negara Republik Indonesia Tahun 1945 (selanjutnya disingkat

${ }^{1}$ Penulis adalah Staf Pengajar pada Fakultas Hukum Universitas Katolik Santo Thomas Medan Sumatera Utara. Alamat kontak: johnshmhum@yahoo.com. 
UUD 1945). Alinea keempat Pembukaan UUD 1945 menyebutkan tujuan nasional yaitu (1) melindungi segenap bangsa Indonesia dan seluruh tumpah darah Indonesia; (2) memajukan kesejahteraan umum; (3) mencerdaskan kehidupan bangsa; dan (4) ikut melaksanakan ketertiban dunia yang berdasarkan kemerdekaan, perdamaian abadi dan keadilan sosial.

Jika mencermati tujuan nasional tersebut sesungguhnya dijiwai oleh silasila Pancasila sebagai dasar negara, khususnya sila kelima dan kedua yaitu "keadilan sosial bagi seluruh rakyat Indonesia" dan "kemanusiaan yang adil dan beradab". Sila kelima Pancasila itu mencerminkan bahwa Indonesia adalah negara kesejahteraan yang bercita-cita untuk mewujudkan kesejahteraan umum. Di samping itu, di dalam Pancasila itu juga sudah terkandung jaminan akan hak asasi manusia (HAM) khususnya untuk diperlakukan secara adil dan manusiawi (beradab) atau yang dikenal dengan sila kedua Pancasila yaitu "Kemanusiaan yang adil dan beradab".

Pengukuhan UUD 1945 pada tanggal 18 Agustus 1945 sebagai konstitusi negara telah membuka peluang penyelenggaraan negara yang sedapat mungkin memprioritaskan kesejahteraan umum (baca: masyarakat). Dalam perjalanan UUD 1945 sejauh ini kesejahteraan umum belum menjadi kenyataan, masih terlalu banyak warga negara yang dikategorikan miskin. Penyelenggara negara menyadari kondisi tersebut yang kemudian mengambil langkah strategis dengan melakukan amandemen UUD 1945 dengan tujuan akhir adalah agar tercipta kesejahteraan umum.

Amandemen Pasal 1 ayat (3) UUD 1945 semakin memperjelas paham negara hukum terkait erat dengan negara kesejahteraan (welfare state) atau paham negara hukum materiil sesuai dengan bunyi aliena keempat Pembukaan dan ketentuan Pasal 34 UUD 1945. Implementasi paham negara hukum materiil akan mendukung dan mempercepat terwujudnya negara kesejahteraan di Indonesia. Demi terwujudnya negara kesejahteraan, maka harus dimulai dari penegakan supremasi hukum (supremacy of law) yang berarti memposisikan hukum sebagai panglima dalam penyelenggaraan negara. Salah satu unsur penting dari paham negara hukum adalah ditegakkannya prinsip-prinsip demokrasi yang senyawa dengan UUD 1945, khususnya Pasal 1 ayat (2) "kedaulatan berada di tangan rakyat dan dilaksanakan menurut UndangUndang Dasar".

Implementasi lebih lanjut dari prinsip-prinsip demokrasi dimaksud adalah dengan terbentuknya masyarakat madani. Dalam masyarakat madani, rakyat diberi kebebasan untuk berkiprah sesuai dengan peradaban dan nilainilai yang tumbuh serta berkembang dalam masyarakat. ${ }^{2}$ Eksistensi masyarakat madani sebagai mitra negara in casu pemerintah dalam menyejahterakan masyarakat, bahkan dapat mengingatkan pemerintah untuk selalu berpedoman pada cita-cita dan tujuan dibentuknya negara. Oleh karena itu, sebagai negara hukum, maka individu dan negara berdiri sejajar. Negara diatur oleh konstitusi dan undang-undang. Konsekuensi logisnya, keadilan merupakan conditio sine

${ }^{2}$ Hidayat Nur Wahid, "Bunga Rampai Komisi Yudisial dan Reformasi Peradilan", (Jakarta: Komisi Yudisial Republik Indonesia, 2007), hal. 187. 
quanon dalam membimbing kehidupan berbangsa dan bernegara. Keadilan bagi semua orang yang dikenal dengan sebutan "equality before the law". Itulah hakikat dan salah satu unsur utama negara hukum.

Dengan tetap memegang teguh keadilan sebagai hakikat negara hukum, negara hukum Indonesia juga memasuki era negara hukum babak baru sebagai negara yang berkemanusiaan. Moral kemanusiaan dipatok sebagai harga tertinggi yang harus dicapai dalam bernegara hukum. ${ }^{3}$ Dalam pandangan Satjipto Rahardjo, negara hukum tidak selesai dibangun hanya dengan memasang papan nama "Negara Hukum". Itu baru awal karena masih banyak yang harus dibereskan (penulis: diperjuangkan), misalnya kita masih perlu memikirkan bagaimana cara berhukum yang ideal agar negara hukum benarbenar dapat menjadi rumah yang membahagiakan rakyatnya. ${ }^{4}$ Tujuan pemerintah dan tujuan hukum haruslah "kebahagiaan terbesar komunitas" atau "kebahagiaan masyarakat. ${ }^{5}$ Jeremy Bentham dan John Stuart Mill dengan rumusan mereka yang sangat populer yaitu "The greatest happiness of the greatest number", 6 mengatakan tujuan hukum adalah untuk memberikan kebahagiaan yang sebesar-besarnya kepada jumlah sebanyak-banyaknya. Lebih lanjut Bentham mengatakan, negara diadakan bukanlah atas kehendak alam, melainkan atas kehendak rakyat melalui suatu bentuk kontrak yang kemudian dijadikan dasar negara. Penciptaan negara melalui kontrak itu dimaksudkan untuk membangun kesejahteraan yang sebesar-besarnya bagi rakyat. Karenanya jika ternyata konstitusi menciptakan keadaan sebaliknya, maka konstitusi itu harus segera diubah untuk mewujudkan tujuan hakikinya. ${ }^{7}$ Artinya, amandemen terhadap konstitusi seperti terhadap UUD 1945 beberapa waktu lalu dimungkinkan dalam kehidupan berbangsa dan bernegara dalam rangka semakin mewujudnyatakan kesejahteraan umum.

${ }^{3}$ Satjipto Rahardjo, Merencanakan Pembangunan Hukum dalam Era Demokrasi, Transparansi dan Perkembangan Sains, makalah disampaikan dalam Seminar \& Temu Hukum Nasional IX Membangun Hukum Nasional yang Demokratis Dalam Tatanan Masyarakat yang Berbudaya dan Cerdas Hukum, Yogyakarta, 20-21 Nopember 2008), hal. 1-2.

${ }^{4}$ Satjipto Rahardjo, Berhukum dengan Akal Sehat, Artikel dalam Harian Umum Kompas, 19 Desember 2008, hal. 6.

5 Jeremy Bentham, "Teori Perundang-Undangan, Prinsip-Prinsip Legislasi, Hukum Perdata dan Hukum Pidana", (Bandung: Nusamedia \& Nuansa, 2006), hal. 2.

${ }^{6}$ J. W. Harris, "Legal Philosophies", (London: Butterworths, 1980), hal. 36. Lihat juga Roscoe Pound, "Pengantar Filsafat Hukum", ed. Mohamad Radjab, (Jakarta: Brahtara, 1989), hal. 42.

${ }^{7}$ Lili Rasjidi dan I. B. Wijaya Putra, "Hukum Sebagai Suatu Sistem", (Bandung: Mandar Maju, 2003), hal. 117. 


\section{Pembangunan yang Berorientasi kepada Kesejahteraan Umum}

Pembangunan nasional terutama pembangunan bidang hukum dan ekonomi dengan dukungan bidang-bidang lainnya, harus berorientasi kepada kesejahteraan umum. Hal tersebut harus dimulai dengan memahami dengan baik semangat pembangunan nasional itu yang telah tercantum dalam Pembukaan UUD 1945 baik pembangunan di bidang hukum maupun pembangunan di bidang ekonomi. Kemudian pemerintah mempertegasnya dalam Undang-Undang Negara Republik Indonesia Nomor 17 Tahun 2007 tentang Rencana Pembangunan Jangka Panjang Nasional Tahun 2005-2025, bahwa keberhasilan pembangunan nasional dalam mewujudkan visi Indonesia yang mandiri, maju, adil, dan makmur perlu didukung oleh (1) komitmen dari kepemimpinan nasional yang kuat dan demokratis; (2) konsistensi kebijakan pemerintah; (3) keberpihakan kepada rakyat; dan (4) peran serta masyarakat dan dunia usaha secara aktif. Dalam konteks diskursus ini, butir ketiga itulah yang seyogianya menjadi fokus perhatian pemerintah dalam berbagai kebijakan implementatif demi terwujudnya kesejahteraan umum.

Pasal 33 ayat (1) sampai dengan (4) UUD 1945 adalah satu-satunya pasal di dalam UUD 1945 yang menunjuk pada sistem ekonomi, sehingga merupakan asas dasar bagi perekonomian nasional, yang terang-terangan antiliberal. Demokrasi ekonomi ditegaskan oleh Pasal 33 ayat (1) UUD 1945 yang menyatakan "...Perekonomian disusun sebagai usaha bersama berdasarkan atas asas kekeluargaan". Menurut Sri Edi Swasono, usaha bersama dimaksud adalah suatu mutualism dan asas kekeluargaan adalah brotherhood. Ini berarti bahwa paham filsafat dasar kita adalah kolektivisme/ komunitarianisme, bukan individualisme. Itulah sebabnya sesuai paham kolektivisme/komunitarianisme yang berdasar mutualism dan brotherhood, maka kepentingan masyarakat ditempatkan sebagai utama, sebagaimana disebutkan dalam Penjelasan Pasal 33 UUD 1945 “...dalam demokrasi ekonomi kemakmuran masyarakatlah yang diutamakan bukan kemakmuran orang seorang...”. Dengan kata lain, kemakmuran masyarakat dan kedudukan rakyat ditempatkan dalam posisi substansial. Inilah ciri sosialistik Pasal 33 UUD 1945. Di sinilah doktrin, demokrasi ekonomi Pasal 33 UUD $1945 .^{8}$ Jadi, Pasal 33 UUD 1945 telah memberikan arahan kepada penyelenggara negara bagaimana membangun bidang ekonomi yang berpihak kepada kesejahteraan umum.

\section{Indonesia sebagai Negara Kesejahteraan}

Jika kita dengan seksama mencermati butir-butir Pembukaan UUD 1945 akan sampai pada suatu penegasan bahwa Indonesia diposisikan sebagai negara kesejahteraan. Relevan dengan penegasan tersebut Siswono Yudo Husodo

${ }^{8}$ Sri Edi Swasono, “Pasal 33: Posisi Rakyat Substansial, bukan Residual," Newsletter Komisi Hukum Nasional 9, No. 1 (Januari - Februari 2009): hal. 5. 
menyatakan "negara kita didesain sebagai Negara Kesejahteraan (welfare state), yang berdasarkan definisi singkat adalah suatu negara, dimana pemerintahan negara dianggap bertanggung jawab menjamin standar kesejahteraan hidup minimum bagi setiap warga negaranya". ${ }^{9}$

Para pendiri negara (the founding fathers) bangsa kita dalam merumuskan cita-cita bernegara melalui UUD 1945 membentuk negara kesejahteraan (welfare state). Pembukaan UUD 1945 menunjukkan niat membentuk negara kesejahteraan itu: ...."Pemerintah melindungi segenap bangsa dan seluruh tumpah darah, memajukan kesejahteraan umum dan mencerdaskan kehidupan bangsa". Cita-cita negara kesejahteraan itu juga tercermin dalam Pasal 27 UUD 1945 yang menyatakan, "setiap warga negara berhak atas pekerjaan dan penghidupan yang layak bagi kemanusiaan dan Pasal 31 yang menjamin hak tiap warga negara untuk mendapatkan pendidikan. Begitu pula Pasal 33 dan 34 UUD 1945 sebagai pasal implementatif dari Pembukaan UUD 1945 yang mengamanatkan pengelolaan kekayaan alam untuk sebesar-besar kemakmuran rakyat serta fakir miskin dan anak terlantar dipelihara negara.

De facto, saat ini makin jauhlah cita-cita kebersamaan yang dulu dicanangkan oleh para founding fathers negeri ini. Gagasan-gagasan cemerlang mereka nyaris tak lagi bergema. Padahal kalau direfleksikan lagi, gagasangagasan yang tak terwujudkan itu, bila sungguh diusahakan, akan memberi dukungan bagi perkembangan tiap warga negara yang ada di republik ini. Sebagai contoh, gagasan sistem kekeluargaan bagi perekonomian nasional dalam Pasal 33 UUD 1945 mencerminkan pentingnya harta kekayaan negara dikelola demi kepentingan umum, bukan hanya demi kepentingan daerah dan/atau kelompok tertentu. ${ }^{10}$

Sesuai dengan paham negara kesejahteraan (welfare state) yang membenarkan negara ikut campur dalam segala bidang kehidupan demi menjamin kesejahteraan warga negaranya. Negara tidak bisa lagi hanya sekedar menjadi penjaga malam (nachtwakerstaat) yang hanya bertugas menjaga ketertiban dan keamanan, agar akibat-akibat yang sudah dan akan ditimbulkan oleh globalisasi (sebagaimana dulu juga pernah ditimbulkan oleh industrialisasi seperti terciptanya jurang yang lebar dalam masyarakat dan stratifikasi sosial yang sangat mencolok) dapat diatasi dan dicegah atau diminimalisasi kemungkinan terjadinya. ${ }^{11}$

Waktu yang tepat untuk mewujudkan kesejahteraan umum adalah ketika Indonesia saat ini merupakan bagian yang tidak terpisahkan dari globalisasi.

9 Darmawan Triwibowo dan Sugeng Bahagijo, "Mimpi Negara Kesejahteraan", (Jakarta: Pustaka LP3S Indonesia, 2006), hal. xv.

${ }^{10}$ Al. Andang L. Binawan dan A. Prasetyantoko, "Keadilan Sosial: Upaya Mencari Makna Kesejahteraan Bersama di Indonesia", (Jakarta: Penerbit Buku Kompas, 2004), hal. viii.

11 Arief Hidayat, Menegaskan Kembali Peran Negara di Tengah Melemahnya Kedaulatan Negara di Era Global, Artikel dalam Bunga Rampai: Potret Penegakan Hukum di Indonesia (Jakarta: Komisi Yudisial Republik Indonesia, 2009), hal. 25. 
Bangsa Indonesia justru dapat mengambil manfaat dari globalisasi yaitu terciptanya kesejahteraan bagi negara-negara yang siap dan dapat memanfaatkan peluang yang muncul pada era global, selain itu demokratisasi di berbagai negara, kemajuan ilmu pengetahuan dan teknologi, pengakuan dan penghormatan terhadap hak asasi manusia (HAM), serta perhatian yang lebih besar pada pelestarian lingkungan hidup. Tentu saja ada syaratnya, bangsa Indonesia harus mampu berkompentensi terutama pada produk barang, jasa, ilmu pengetahuan dan teknologi, perbaikan kerusakan lingkungan, kondisi yang kondusif dalam berdemokrasi dan mengurangi adanya pelanggaran HAM.

Jika bangsa kita tidak mampu berkompetensi, maka yang terjadi adalah bangsa Indonesia tergilas oleh globalisasi. Ekses yang paling nyata menyebabkan kemiskinan, kerusakan lingkungan hidup, terjadinya erosi budaya yang luar biasa, disintegrasi, penyakit menular, dan kejahatankejahatan transnasional terorganisasi yang dapat disebut sebagai bahaya keamanan non-tradisional seperti trafficking, perdagangan narkotika, perdagangan senjata api, terorisme, illegal logging, dan perompakan di laut, yang pada hakikatnya dapat dikatakan merupakan globalisasi kejahatan.

Mencermati dampak besar yang terjadi jika bangsa kita tidak mampu berkomptensi, maka negara in casu pemerintah harus mengambil langkah cepat dan tegas memanfaatkan dampak positif globalisasi, agar masalah kemiskinan yang memang sudah sangat mencemaskan tidak semakin parah. Artinya negara sangat berperan untuk mencegah meningkatnya jumlah warga negara yang miskin, dan berusaha sekuat tenaga dengan memaksimalkan kemampuan sumber daya alam sebagaimana diamanatkan oleh Pasal 33 ayat (3) UUD 1945 mengurangi jumlah warga negara yang miskin. ${ }^{12}$ Dalam Pasal 33 Ayat (3) UUD 1945 dinyatakan "bumi dan air dan kekayaan alam yang terkandung di dalamnya dikuasai oleh negara dan dipergunakan untuk sebesar-besar kemakmuran rakyat". Dengan demikian, ada potensi yang sangat besar untuk menyejahterakan masyarakat yang berarti menghindari masyarakat dari kemiskinan.

Dalam konsep Siswono Yudo Husodo, kesejahteraan adalah buah dari sistem ekonomi negaranya yang mandiri, produktif dan efisien dengan pendapatan individu yang memungkinkan saving. ${ }^{13}$ Dengan format negara kesejahteraan seperti di Eropa Barat dan Eropa bagian Utara, menunjukkan bahwa negara mampu memikul beban yang aktif dalam pengurangan kemiskinan, penyediaan lapangan kerja yang luas, sistem kesehatan dan

${ }^{12}$ Penulis tidak sependapat kalau masalah kemiskinan itu sering disebut "angka kemiskinan", karena angka kemiskinan umumnya berbeda antara versi pemerintah dan masyarakat seperti LSM yang secara nyata melihat langsung warga negara yang tergolong miskin. Pemerintah terlalu mudah menyatakan bahwa angka kemiskinan sudah menurun drastis, sementara de facto dalam masyarakat warga negara yang miskin (jumlah orang miskin) bertambah banyak dan semakin sulit sekedar mempertahankan hidup, tidak lagi memikirkan pendidikan dasar anak-anaknya apalagi untuk mendapat pelayanan kesehatan secara gratis.

13 Siswono Yudo Husodo, "Menuju Welfare State, Kumpulan Tulisan Tentang Kebangsaan, Ekonomi, dan Politik", (Jakarta: Baris Baru, 2009), hal. 65. 
pendidikan yang terjangkau warga, jaminan sosial yang memadai serta sistem transportasi yang murah sebagai kebutuhan masyarakatnya. ${ }^{14}$

Menurut Esping Andersen (1990), negara kesejahteraan pada dasarnya, mengacu pada "peran negara yang aktif dalam mengelola dan mengorganisasi perekonomian" yang di dalamnya mencakup tanggung jawab negara untuk menjamin ketersediaan pelayanan kesejahteraan dasar dalam tingkat tertentu bagi warganya". ${ }^{15}$ Secara umum, suatu negara bisa digolongkan sebagai negara kesejahteraan jika mempunyai empat pilar utamanya, yaitu: (i) social citizenship; (ii) full democracy; (iii) modern industrial relation system; (iv) rights to education and the expansion of modern mass education systems. ${ }^{16}$

Keempat pilar ini dimungkinkan dalam negara kesejahteraan karena negara memperlakukan penetapan kebijakan sosial sebagai "penganugerahan hak-hak sosial" (the granting of social rights) kepada warganya. Hak-hak sosial tersebut mendapat jaminan seperti layaknya hak atas properti, tidak dapat dilanggar (inviolable) serta diberikan berdasar basis kewargaan (citizenship) dan bukan atas dasar kinerja atau kelas. ${ }^{17}$ Jadi, jika negara sungguh-sungguh menyadari cita-cita negara kesejahteraan sebagaimana telah disepakati para bapak pendiri negara (founding fathers) dan melakukan tindakan nyata melalui berbagai kebijakan publik yang berpihak ke warga negara serta pengalokasian dana yang besar, niscaya persoalan kemiskinan mulai menunjukkan pengurangan yang signifikan. Tentu saja dengan mempertimbangkan faktor-faktor yang melingkupi masalah kemiskinan, seperti politik, cara memandang kemiskinan dan budaya yang justru melanggengkan kemiskinan itu.

\section{Hukum Sebagai Panglima Menuju Kesejahteraan umum}

Saat ini usia negara hukum Indonesia 65 tahun, tetapi keberpihakan hukum terhadap warga negara yang tergolong miskin belum membumi, artinya keberpihakan itu masih pada tataran retorika politik di kalangan elit politik. Hukum belum berposisi secara maksimal dalam penyelenggaran kehidupan berbangsa, bernegara dan bermasyarakat khususnya hukum yang menyejahterakan masyarakat.

Menyimak kondisi tersebut, tetap relevan kritik Neo-Marxis tentang keberpihakan hukum sangat jelas. Ia (baca: hukum) menguntungkan golongan kaya dan merugikan serta menipu golongan miskin. Dengan begitu, secara tersembunyi institusi-institusi hukum telah tercemar dan ikut menyebabkan ketiadaan ketertiban sosial secara keseluruhan. Ia bekerja sebagai alat

\footnotetext{
${ }^{14}$ Ibid., hal. xvii.

${ }^{15}$ Darmawan Triwibowo dan Sugeng Bahagijo, Op. Cit., hal. 9.

${ }^{16}$ Ibid.

${ }^{17} \mathrm{Ibid}$.
} 
kekuasaan. ${ }^{18}$ Kritik berikutnya dari Neo-Marxis adalah legalisme liberal (liberal legalism), khususnya mengenai gagasan bahwa tujuan keadilan dapat dicapai melalui sistem peraturan dan prosedur yang obyektif, tidak memihak, dan otonom.

Menurut Neo-Marxis, faktual, the rule of law tidak mampu mengatasi isu-isu mendasar mengenai keadilan sosial. Lebih buruk lagi, rule of law merupakan "musuh tersembunyi" (hidden enemy) bagi keadilan sosial itu sendiri. ${ }^{19}$ Bukan keadilan sosial yang diraih dalam rule of law, tetapi kemenangan orang-orang yang mapan dan kaya. Pengadilan, bukan tempat orang-orang kelas bawah mendapatkan keadilan sosial, tetapi menjadi mimbar dari kelas atas mengadili kelas bawah. ${ }^{20}$

Posisi hukum sebagai panglima akan kelihatan bagaimana hukum meregulasi kebijakan dan penataan ekonomi yang berorientasi keadilan sosial. Sebab, suatu sistem ekonomi dapat mempunyai pengaruh yang sedemikian besar dalam kehidupan masyarakat. John Rawls yang gigih memperjuangkan keadilan sosial juga percaya sistem ekonomi sangat berpengaruh terhadap kesejahteraan umum. Sistem ekonomi dapat saja mempengaruhi keinginankeinginan dan aspirasi-aspirasi masyarakat. Sistem yang sama juga dapat mempengaruhi masa depan, bahkan ikut menentukan kualitas hidup serta kepribadian seseorang. ${ }^{21}$ Dalam rumusan Rawls, sistem ekonomi mempengaruhi keinginan-keinginan serta aspirasi-aspirasi yang ingin dimiliki oleh warga. Sistem itu untuk sebagian juga menentukan kepribadian ideal seseorang, sama juga seperti menentukan kepribadian manusia yang de facto ada. $^{22}$

Dalam tradisi Gereja Katolik, keadilan sosial dikaitkan dengan kesejahteraan umum, yang dirumuskan sebagai "keseluruhan kondisi-kondisi hidup kemasyarakatan, yang memungkinkan baik kelompok-kelompok maupun anggota-anggota perorangan, untuk secara lebih penuh dan lebih lancar mencapai kesempurnaan mereka sendiri. ${ }^{23}$ Relevan dengan keadilan sosial sebagai jalan terwujudnya kesejahteraan umum, Franz Magnis Suseno

${ }^{18}$ Bernard L. Tanya, dkk, "Teori Hukum, Strategi Tertib Manusia Lintas Ruang dan Generasi", (Surabaya: CV KITA, 2006), hal. 169.

19 Philippe Nonet and Philip Selznick, "Law and Society in Transition: Toward Responsive Law", (London: Harper and Row Publisher, 1978), hal. 5. Baca juga Philippe Nonet dan Philip Selznick, "Hukum Responsif", (Bandung: Penerbit Nusamedia, 2007), hal. 5.

${ }^{20}$ Benard L. Tanya (et al.)., Op. Cit., hal. 170.

${ }^{21}$ Andre Ata Ujan, "Keadilan dan Demokrasi, Telaah Filsafat Politik John Rawls", Seri Filsafat Atmajaya: 23 (Yogyakarta: Penerbit Kanisius, 1999), hal. 114.

${ }^{22}$ Ibid.

${ }^{23}$ Konstitusi Pastoral tentang Gereja di Dunia Dewasa ini (atau lebih dikenal sebagai "Gaudium et Spes", dalam Dokumen Konsili Vatikan II (Jakarta: Dokumentasi Penerangan KWI/Obor, 1993), No. 26, hal. 539. 
mengapresiasinya dengan menyatakan bahwa pilihan keadilan sosial sebagai salah satu tiang negara merupakan buah kecerdasan yang dimiliki oleh para pendiri negara (founding fathers) dalam melihat karakter dan suasana hati rakyat Indonesia. Sebagai sebuah pijar yang akan menuntun ke mana arah negara, tentu saja tiang keadilan sosial tersebut harus diwujudkan dengan segala konsekuensi biaya yang mungkin timbul. ${ }^{24}$ Dari deskripsi itu tampak bahwa keadilan sosial merupakan salah satu filsafat politik yang mendasari berdirinya Indonesia. Dalam pengelolaan negara, filsafat politik - dalam politik keseharian - tersebut selalu harus berhadapan dengan pertanyaan legitimasi, yakni legitimasi dalam pengertian etis. ${ }^{25}$

\section{Kebijakan Negara yang Berpihak kepada Warga Miskin}

Kebijakan negara in casu pemerintah yang berpihak kepada warga yang miskin atau yang biasa disebut option for the pro poor, seyogianya bersifat implementatif dari Pancasila sebagai falsafah Negara, terutama sila ke-lima dan ke-dua, Pembukaan Alinea ke empat Pasal 33 dan 34 UUD 1945 yang harus tercermin di dalam berbagai kebijakan publik dalam bentuk peraturan perundang-undangan. Dalam kategori Conhran dan Malone, sebuah kebijakan dimaknai sebagai publik (kebijakan publik) bila kebijakan tersebut berkaitan dengan keputusan dan tindakan pemerintah yang didesain untuk menyelamatkan persoalan rakyat (public concern). Tentu saja persoalan rakyat yang dimaksud adalah kemiskinan. Jadi sepanjang urusan itu berkaitan dengan tujuan keadilan sosial sebagai filsafat politik berdirinya negara, maka dengan cepat hal itu dapat direspons sebagai hajat hidup publik. ${ }^{26}$

Kebijakan publik yang pro poor harus peka terhadap perbedaanperbedaan sosial dan ekonomi, dan secara aktif menangani ketidaksetaraan tersebut. Seringkali, kebijakan-kebijakan seperti ini mendukung pelayanan publik dasar seperti kesehatan, pendidikan, perumahan, air, sebab secara eksplisit menargetkan mereka yang tidak mampu membayar pelayanan swasta (di sektor swasta pelayanan-pelayanan tersebut perlu diatur dan dikelola, tetapi tidak harus disubsidi). Karena kemiskinan juga disebabkan oleh ekslusi, kebijakan pro poor harus memungkinkan orang miskin dan keluarga-keluarga yang tidak beruntung untuk terlibat dalam pembuatan keputusan publik. Kebijakan pro poor yang sedemikian ini diadoposi di dalam sepuluh hak dasar di dalam Strategi Nasional Pengentasan Kemiskinan di Indonesia yang meliputi makanan, kesehatan, pendidikan, pekerjaan, perumahan, air bersih dan

${ }^{24}$ Ahmad Erani Yustika, "Negara vs. Kaum Miskin”, (Yogyakarta: Pustaka Pelajar, 2003), hal. 3.

${ }^{25}$ Franz Magnis Suseno, "Filsafat Sebagai Ilmu Kritis", (Yogyakarta: Penerbit Kanisius, 1992), hal. 23.

${ }^{26}$ Ibid., hal. 8. 
sanitasi, tanah, sumberdaya alam dan lingkungan, keamanan manusia, dan partisipasi. $^{27}$

Kebijakan pro poor mencakup:

1. Kebijakan redistributif, seperti pajak progresif, subsidi, dan landreform.

2. Kebijakan tindakan afirmatif untuk menangani ketidaksetaraan sosial:

a. Program-program pemberdayaan, termasuk kuota untuk perempuan di parlemen.

b. Perumahan yang memadai untuk orang miskin.

c. Sekolah dan pelayanan kesehatan gratis untuk keluarga-keluarga berpenghasilan rendah, dan

d. Peluang kerja alternatif ketika tergusur.

3. Penciptaan lapangan kerja berkelanjutan bagi keluarga-keluarga berpenghasilan rendah.

4. Akses pada kredit mikro yang murah (seperti grameen Bank).

5. Perencanaan dan penganggaran partisipatif yang berbasis luas dan difasilitasi, di mana kebutuhan orang miskin diprioritaskan dengan indikator kinerja yang jelas untuk memastikan bahwa target-target tercapai, dan

6. Anggaran berbasis kinerja yang berangkat dari program-program yang memiliki kegiatan dan indikator-indikator serta ukuran hasil yang teridentifikasi dengan jelas, yang ditargetkan untuk kelompokkelompok marginal. ${ }^{28}$

Salah satu definisi penganggaran pro poor adalah bahwa ia merupakan suatu cara sadar menangani ketidaksetaraan dan ketidakadilan di dalam proses penganggaran biasa. Contoh anggaran yang pro poor:

1. Dana umum yang dialokasikan untuk pelayanan dasar manusia dan insfrastruktur publik, seperti pendidikan, pelayanan kesehatan, dan jalan-jalan pedesaan yang terutama akan menguntungkan orang miskin.

2. Alokasi anggaran untuk mensubsidi pelayanan publik (pelayanan kesehatan dan pendidikan gratis).

3. Alokasi anggaran yang sensitif gender untuk perempuan (seperti pelatihan bidan dan penyediaan tempat penitipan anak umum).

4. Dana yang disisikan untuk pemberdayaan ekonomi bagi kelompokkelompok yang rentan terhadap kemiskinan, seperti nelayan dan petani/pedagang kecil.

5. Insentif finansial bagi perusahaan-perusahaan untuk mempekerjakan orang cacat, membangun pabrik di luar kota, atau melatih buruh-buruh kasar, dan

${ }^{27}$ Antonio Pradjasto Hardojo, dkk, "Mendahulukan Si Miskin", (Yogyakarta: LKiS, 2008), hal. ix

${ }^{28}$ Ibid., hal. x. 
6. Dana darurat untuk penanganan bencana (pro aktif, bukan post facto). ${ }^{29}$

Kebijakan dan anggaran pro poor penting dikedepankan mengingat masalah klasik yang dihadapi bangsa Indonesia adalah terjadinya ketimpangan negara dalam implementasi keadilan sosial yang melahirkan persoalan kemiskinan yang membelit rakyatnya. Persoalan kemiskinan adalah suatu problema struktural yang membelenggu masyarakat Indonesia sejak era prakemerdekaan hingga saat ini. Problema kemiskinan muncul karena adanya disparitas ekonomi dan lemahnya otoritas negara dalam mengkondisikan iklim keadilan sosial sesuai amanah UUD $1945^{30}$

Sebagaimana diketahui secara umum bahwa kemiskinan di Indonesia telah membatasi hak rakyat untuk:

1. Memperoleh pekerjaan yang layak bagi kemanusiaan.

2. Memperoleh perlindungan hukum.

3. Memperoleh rasa aman.

4. Memperoleh akses atas kebutuhan hidup (sandang, pangan, papan) yang terjangkau.

5. Mengakses kebutuhan pendidikan.

6. Memperoleh akses atas kebutuhan kesehatan.

7. Memperoleh keadilan.

8. Ikut berpartisipasi dalam pengambilan keputusan publik dan pemerintahan.

9. Untuk berinovasi.

10. Berpartisipasi dalam menata dan mengelola pemerintahan dengan baik. $^{31}$

Pembatasan hak-hak rakyat akibat kemiskinan, mengingatkan kita untuk menggugat eksistensi negara, dengan pertanyaan, apa tujuan kita bernegara? Para founding fathers telah menetapkan tujuan bernegara, bahwa negara dibangun dan dibentuk untuk menciptakan kehidupan bersama yang sejahtera, aman dan berkeadilan. Untuk itu negara juga harus concern terhadap kenyataan yang timpang mendera rakyat miskin terkait dengan hak-hak hukumnya, politik, sipil dan yang sangat terkait dengan kemiskinan itu adalah hak-hak ekonomi, sosial dan budaya.

Sudah menjadi rahasia umum, bahwa rakyat miskin di negeri yang gemah ripah loh jinawi ini seringkali terpinggirkan dan luput dari perhatian. Nasib rakyat miskin masih jauh dari praktik-praktik yang adil. Dalam banyak kasus rakyat miskin justru sering menjadi korban ketidakadilan. Kasus-kasus penggusuran menjadi contoh nyata bagaimana subyek ketidakberdayaan

${ }^{29}$ Ibid., hal. xii.

${ }^{30}$ Heru Nugroho, Negara Sebagai Instrumen Untuk Mewujudkan Keadilan Sosial: Konteks Indonesia, Artikel dalam Bunga Rampai: Potret Penegakan Hukum di Indonesia (Jakarta: Komisi Yudisial Republik Indonesia, 2009), hal. 53.

${ }^{31}$ Ibid., hal. 55. 
dipaksa semakin tidak berdaya oleh state apparatus. ${ }^{32}$ Seringkali aparatur negara melakukan penggusuran terhadap warga negara yang memang sudah berada dalam kondisi marginal dengan serta merta menjadi semakin miskin. Penggusuran seringkali tanpa menawarkan solusi yang tepat bagi warga negara yang marginal. Solusi semata-mata hanya menyediakan tempat penampungan yang baru tetapi tidak memberikan jaminan bahwa mereka tetap mendapatkan penghasilan untuk memenuhi kebutuhan hidupnya.

Relevan dengan kondisi diskriminatif tersebut, J. E. Sahetapy, menyatakan dalam dunia penegakan hukum faktor kemiskinan juga menjadi faktor penghambat dalam rangka menegakkan keadilan dan kebenaran, terlepas dari kemiskinan yang endemiknya di Indonesia itu, yang oleh John Perkins dalam bukunya "Confession of an economic bit man" (2004) dikatakan, "apakah karena kemiskinan struktural, kemiskinan karena faktor politikekonomi-sosial-budaya, kemiskinan karena dampak globalisasi dengan faktor (neo) liberalisme, (neo) kapitalisme ataupun (neo) kolonialisme. ${ }^{33}$ Negara dituntut mampu mengatasi berbagai penyebab kemiskinan dengan berbagai kebijakan yang efisien dan efektif.

Indonesia sebagai bagian dari masyarakat internasional, maka pemerintah juga penting sekali melaksanakan Konvensi Internasional tentang Hak-Hak Ekonomi, Sosial dan Budaya yang merupakan perumusan lebih lanjut "Declaration Universal of Human Rights" atau Deklarasi Universal Hak Asasi Manusia (DUHAM) seperti hak atas standar kehidupan yang layak. Deklarasi universal HAM di Paris, 10 Desember 1948 itu, khususnya hak-hak ekonomi, sosial dan budaya yang diperjelas dalam Konvensi Internasional tentang HakHak Ekonomi, Sosial dan Budaya merupakan ajakan moral internasional kepada setiap negara anggota PBB agar memperhatikan hak atas standar kehidupan yang layak, dengan sendirinya mensyaratkan pemenuhan hak atas pakyan, perumahan, dan pangan.

Standar akan kehidupan yang layak mensyaratkan ketersediaan sumbersumber ekonomi. Dengan demikian, hak-hak sosial dapat dipenuhi bila hakhak ekonomi terpenuhi, seperti hak atas pekerjaan, upah yang layak, dan hak atas jaminan sosial. ${ }^{34}$ Hak-hak ekonomi, selain menjadi dasar bagi terpenuhinya hak-hak sosial, juga dipengaruhi oleh pemenuhan hak-hak sipil dan politik terutama kebebasan. ${ }^{35}$

${ }^{32}$ Komisi Hukum Nasional Republik Indonesia, Newsletter, Negara Tidak Peduli Rakyat Miskin, Vol. 9, No. 2 (Maret - April 2009: hal. 3.

${ }^{33}$ J. E. Sahetapy, Selamat Datang Kemiskinan, catatan lepas dalam Newsletter, Komisi Hukum Nasional Tepublik Indonesia, Vol. 9, No. 2 (Maret - April 2009): hal. 35.

${ }^{34}$ Naning Mardiniah (et al.), "Meneropong Hak Atas Pendidikan dan Layanan Kesehatan, Analisis Situasi di Tiga Kabupaten: Indramayu, Sikka, dan Jayapura", (Jakarta: LP3ES, 2005), hal. 14.

${ }^{35}$ Ibid. 
Terkait dengan kebebasan yang dimaksud, kita perlu kembali ke hukum. Hukum, sebagaimana ditegaskan oleh penganut teori hukum kodrat maupun positivisme hukum, bertujuan menciptakan tatanan sosial (social order) demi melindungi dan menjamin kepentingan umum. Dalam arti ini, hukum sebetulnya memainkan peran paradoksal: di satu sisi, hukum memfasilitasi kebebasan masyarakat untuk mengejar dan merealisasi kepentingannya. Akan tetapi, pada sisi yang lain, hukum membatasi ruang kebebasan masyarakat. Dengan adanya hukum, masyarakat tidak dapat lagi bertindak tanpa memperhatikan pentingnya memberi ruang gerak bagi yang lain untuk mengejar dan mewujudkan apa yang dipandangnya berharga dan bernilai bagi dirinya. Dengan adanya hukum, kebebasan yang digunakan secara sewenang-wenang dalam situasi alamiah, atau prejuridical society dalam bahasa Immanuel Kant, untuk memenangkan kepentingan sendiri, kini diatur dan dibatasi sehingga pelaksanaannya tidak melanggar hak dan kepentingan pihak lain. Masyarakat hukum, atau yang oleh Immanuel Kant disebut juridical society, menuntut bahwa pelaksanaan hak harus disertai dengan ketersediaan memikul kewajiban dan tanggung jawab demi kebaikan bersama. ${ }^{36}$

\section{Kesimpulan}

Indonesia sebagai negara kesejahteraan (welfare state) sebagaimana telah tersurat dalam Pembukaan UUD 1945 akan terwujud jika negara berperan aktif dalam mengelola dan mengorganisasi perekonomian sebagaimana dimaksud Pasal 33 UUD 1945 yang di dalamnya mencakup tanggung jawab negara untuk menjamin ketersediaan pelayanan kesejahteraan dasar dalam tingkat tertentu bagi warganya". Negara memberlakukan kebijakan publik termasuk hukum berupa penganugerahan hak-hak sosial" (the granting of social rights) kepada warga negara. Pengorganisasian perekonomian didukung oleh peraturan perundang-undangan yang dijiwai semangat cita-cita nasional dalam Pembukaan UUD 1945 dan terutama Pasal 33 dan 34 UUD 1945. Bersamaan dengan itu, segera menyelesaikan faktor-faktor yang melingkupi masalah kemiskinan, seperti cara pandang terhadap masalah kemiskinan dan budaya yang justru melanggengkan kemiskinan itu.

${ }^{36}$ Andre Ata Ujan, "Filsafat Hukum", (Yogyakarta: Penerbit Kanisius, 2009), hal. 123. 


\section{Daftar Pustaka}

\section{Buku-Buku}

Bentham, Jeremy. Teori Perundang-Undangan, Prinsip-Prinsip Legislasi, Hukum Perdata dan Hukum Pidana, Bandung: Nusamedia \& Nuansa, 2006.

Binawan, Al. Andang L. dan A. Prasetyantoko. Keadilan Sosial: Upaya Mencari Makna Kesejahteraan Bersama di Indonesia, Jakarta: Penerbit Buku Kompas, 2004.

Harris, J. W. Legal Philosophies, London: Butterworths, 1980.

Hardojo, Antonio Pradjasto, dkk. Mendahulukan Si Miskin, Yogyakarta: $L K \mathrm{i} S, 2008$.

Husodo, Siswono Yudo. Menuju Welfare State, Kumpulan Tulisan Tentang Kebangsaan, Ekonomi, dan Politik, Jakarta: Baris Baru, 2009.

Mardiniah, Naning, et al. Meneropong Hak Atas Pendidikan dan Layanan Kesehatan, Analisis Situasi di Tiga Kabupaten Indramayu, Kabupaten Sikka, dan Kabupaten Jayapura, Jakarta: LP3ES, 2005.

Nonet, Philippe \& Philip Selznick. Law and Society in Transition: Toward Tanggapanive Law, New York, Hagerstown, San Fransisco, London: Harper and Row Publisher, 1978.

. Hukum Responsif. Bandung: Penerbit Nusamedia, 2007.

Pound, Roscoe. Pengantar Filsafat Hukum, Diterjemahkan oleh Mohamad Radjab. Jakarta: Brahtara, 1989.

Rasjidi, Lili, I. B. Wijaya Putra. Hukum Sebagai Suatu Sistem, Bandung: Mandar Maju, 2003.

Suseno, Franz Magnis. Filsafat Sebagai Ilmu Kritis, Yogyakarta: Penerbit Kanisius, 1992

Tanya, Bernard L, dkk. Teori Hukum, Strategi Tertib Manusia Lintas Ruang dan Generasi, Surabaya: CV. KITA, 2006.

Triwibowo, Darmawan dan Sugeng Bahagijo. Mimpi Negara Kesejahteraan, Jakarta: Pustaka LP3ES Indonesia, 2006.

Ujan, Andre Ata. Keadilan dan Demokrasi, Telaah Filsafat Politik John Rawls, Seri Filsafat Atmajaya: 23, Yogyakarta: Penerbit Kanisius, 1999.

. Filsafat Hukum, Yogyakarta: Penerbit Kanisius, 2009.

Yustika, Ahmad Erani. Negara vs. Kaum Miskin, Yogyakarta: Pustaka Pelajar, 2003. 


\section{Makalah dan Artikel}

Hidayat, Arief. "Menegaskan Kembali Peran Negara di Tengah Melemahnya Kedaulatan Negara di Era Global", Artikel dalam Bunga Rampai: Potret Penegakan Hukum di Indonesia. Jakarta: Komisi Yudisial Republik Indonesia, 2009.

Komisi Hukum Nasional Republik Indonesia, Newsletter. "Negara Tidak Peduli Rakyat Miskin", Catatan Redaksi dalam Newsletter. Jakarta: Komisi Hukum Nasional Republik Indonesia, Vol. 9, No. 2, Maret - April 2009.

Konstitusi Pastoral tentang Gereja di Dunia Dewasa ini (atau lebih dikenal sebagai "Gaudium et Spes"), dalam Dokumen Konsili Vatikan II. Jakarta: Dokumentasi Penerangan KWI/Obor, 1993, No. 26.

Nugroho, Heru. "Negara Sebagai Instrumen Untuk Mewujudkan Keadilan Sosial: Konteks Indonesia,". Artikel dalam Bunga Rampai: Potret Penegakan Hukum di Indonesia. Jakarta: Komisi Yudisial Republik Indonesia, 2009.

Rahardjo, Satjipto. "Merencanakan Pembangunan Hukum dalam Era Demokrasi, Transparansi dan Perkembangan Sains". Makalah disampaikan dalam Seminar \& Temu Hukum Nasional IX Membangun Hukum Nasional Yang Demokratis Dalam Tatanan Masyarakat Yang Berbudaya dan Cerdas Hukum. Yogyakarta: 2021 Nopember 2008.

. "Berhukum dengan Akal Sehat". Artikel dalam Harian Umum Kompas, Jakarta: 19 Desember 2008.

Sahetapy, J. E. "Selamat Datang Kemiskinan", Catatan lepas dalam Newsletter. Jakarta: Komisi Hukum Nasional Republik Indonesia, Vol. 9, No. 2, Maret - April 2009.

Swasono, Sri Edi. "Pasal 33: Posisi Rakyat Susbtansial, bukan Residual". Suatu pandangan tentang Prospek Pembangunan Hukum 2009-2014 dalam Newsletter. Jakarta: Komisi Hukum Nasional Republik Indonesia, Vol. 9, No. 1, Januari - Februari 2009.

Wahid, Hidayat Nur. "Komisi Yudisial yang Dicita-citakan oleh Masyarakat dan Pencari Keadilan. Artikel dalam Bunga Rampai Komisi Yudisial dan Reformasi Peradilan. Jakarta: Komisi Yudisial Republik Indonesia, 2007.

\section{Peraturan Perundang-Undangan:}

Indonesia. Undang-Undang Dasar Negara Republik Indonesia Tahun 1945. 
. Undang-Undang tentang Rencana Pembangunan Jangka Panjang Nasional Tahun 2005-2025. UU Nomor 17 Tahun 2007. Lembaran Negara Republik Indonesia Tahun 2007 Nomor 33. Tambahan Lembaran Negara Republik Indonesia Nomor 4700. 